\title{
Mechanization Effect on Farm Practices in Kwara State, North Central Nigeria
}

\author{
Dauda Solomon Musa ${ }^{1}$,JohnJiya Musa ${ }^{2}$ and Desa Ahmad ${ }^{1}$ \\ ${ }^{I}$ Department of Biological and Agricultural Engineering, Faculty of Engineering, Universiti Putra \\ Malaysia,43400 UPM, Serdang, Selangor, Malaysia. \\ ${ }^{2}$ Department of Agricultural and Bioresources Engineering, Federal University of Technology, $P$ M B 65, \\ Minna, Nigeria.
}

\begin{abstract}
The effect of mechanization on arable crops in Edu and Patigi local government areas of Kwara State where the majority of the farmers are beginning to adopt the use of modern technology on their agricultural activities was investigated. The Investigative Research Approach Method was employed to retrieve information from farmers through the use of structured questionnaire. The farmers were randomly selected and a total of one hundred farmers were interviewed in the two local government areas. It was observed that $95 \%$ of the respondents were males while the remaining $5 \%$ were females, $31 \%$ of the farmers were aged between 41 and 50 years and also $98 \%$ of the respondents went through primary, secondary or tertiary education, $75 \%$ of the farmers had less than 10 family members while 68\% of the farmers inherited the land in which they are using for farming. This study also shows that $60 \%$ of the respondents adopted mechanization and it boosted their crop production and reduced the use of other forms of manual labour.
\end{abstract}

Keywords: Arable crops, farmer, mechanization, technology, tractor

\section{INTRODUCTION}

In recent years, tractor power has become a rival to the use of animal draught. In Nigeria, tractors were introduced in the 1950's through farm settlement scheme in the western region of the country before spreading to other parts of the nation (Dauda et al. 2010). Farm tractors are being under-utilized in Nigeria, this was attributed to limited seasonal application of farm tractors and lack of technical and managerial competence to handle, use and maintain farm machinery (Manuwa, 1996, Oni, 2004, Usman and Umar, 2003).

Agricultural mechanization is the application of engineering technology into the field of agriculture, in order to improve agricultural output, as well as deliberate conscious departure from the peasant and subsistence agriculture into a commercial agriculture. This process also involves the development and management of machines for field production, water control, material handling as well as post-harvest operation (Rahman and Lawal, 2003, Owombo et al. 2012).

To some, agricultural mechanization is synonymous with tractorization while others take it to mean increase in production per farmer per hectare of land cultivated. The high cost of ownership of farm tractors in Nigeria presently militates against the use of tractors by majority of the farmers (Rahman and Mijinyawa, 2001).

Nigeria has over $80 \%$ of its populace engaged in agricultural activities from where the people derive their means of livelihood either directly or indirectly.Iheanachoet al., (2003) stated that the machines used for agricultural production in Nigeria include: hand tools, animal drawn implements, two wheel and four-wheel drive tractors, motorized or mechanically driven post-harvest handling and processing machines, crop storage equipment and pumps for irrigation.Thus, agricultural mechanization in Nigeria can be divided into three levels of technology; hand tools technology, draught-animal technology and engine powered technology (Oudman, 1993).

Engine powered agricultural mechanization technology include the use of a wheel range tractor sizes as mobile power for field operations, engines or motors to power such machines as threshers, mills, irrigation pumps, air craft for spraying chemicals and self-propelled machine for production harvesting and handling of wide variety of crops.

Agriculture is the most important economic activity in Nigeria, in terms of revenue (apart from oil sector revenue) especially in the rural areas. According to the national survey conducted by the Federal Ministry Agriculture, itassessed the quality and quantity of food production. The outcome of this was a document on agricultural development in Nigeria between 1973and 1985.The general conclusion from the document was the 
problem of modernization of agriculture through the dissemination of modern technologies for agricultural production (Olukosiet al., 2006). This was to be brought about by investment in mechanical technology programmes through public delivery system such as Agricultural Development Agencies like (ADPs) and other agricultural developmentinstitutions.

Mechanization is a new technology to the farmers in the study area;this is as a result of limited spread of machineuse, the prevalence of small and fragmented farm holding and lack of capital to acquire the machines, and also adverse cultural practices. In addition, illiteracy of the majority of the farming populace, inadequate rural infrastructural facilities (road, water and electricity) unavailability of spare parts, lack of enough trained machinery operators, poor credit facilities inadequate research programmes to cope with foreign technology(CTA,1992).

Mechanization inputs are often subsidized by low prices for tractors and machinery or by providing tractor hire services at less than their true cost. In many countries animal power and equipment are not getting similar support and encouragement. The smallholder farmer, and the national economy, may be disadvantaged in consequence (Kaumbutho, 1996). Another point of consideration is the cost of the labour supply. It is difficult to assess the costs of power in near-subsistence farming where human labour and, in some areas, draught animal power are likely to be the dominating power sources. Consequently it is not possible to make a convincing exact comparison of costs for alternative farming systems under varying degrees of mechanization and with a variety of power sources. Smallholder farmers react mainly to costs paid in cash and cash-equivalent costs involving payments in kind.

Government and its various agencies will probably be more interpreted in economic costs, often involving subtle variations in definition. The availability of cash and cash flow are major problems which limit the farmers' ability to use more power to expand or intensify their production system. For most smallholder farmers, personal and family labour is the most readily available, reliable and cheap source of power. The cost of such labour is not readily identifiable unless there is alternative employment which would bring in a cash income (Kaumbutho, 1996).

The objectives of this study are to determine the socio-economic factors of arable crop farmers; examine the profitability of arable crop production;find out the effect of mechanization on the farm output and to examine the constraints faced by the farmers in the study area.

\section{MATERIALS AND METHOD}

Area of study: Kwara State is located on coordinates $8^{\circ} 30^{\prime} \mathrm{N} 5^{\circ} 00^{\prime}$ Ein the north-central of Nigeria with itscapital at Ilorin. Until 1968, the area was part of North WesternState. Kwarais borderedto the North by River Niger, to the North East by KogiState and to South West by Oyo and Ondo States fig 1.

The occupation of the people of the state is primarily farming. They produce food crops as well as cash crops. Education is given a place of pride in the state. At its creation, the state had a number of educational institutions on ground to cater for the educational needs of its people. The state is comprised of 16 local government areas.

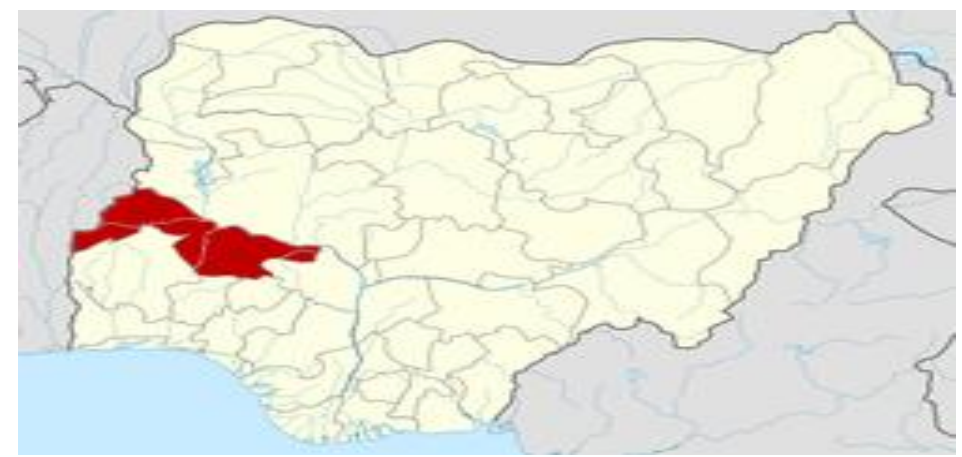

Fig. 1. Map of Nigeria showing the location of Kwara State

Sampling Techniques:The data mainly from primary sources were collected from two Local Government Areas (LGAs) which was selected based on their agricultural activities using multistage sampling technique. The Local Government Areas are Edu and Patigi. Fifty farmers from each of the two Local Government Areas were randomly selected giving a total of 100 respondents. The data/informationwas collected with the use of a designed structured questionnaire.

Data Analysis:Descriptive Statistic was employed such as arithmetic mean, frequency distribution, percentage etc. The technique was used to group and summarize the data obtained from the field. 
Gross margin: This is the difference between the Gross Farm Income (GFI) and the Total Variable Cost (TVC). It is a useful planning tool in situations where fixed capital is negligible portion of the farming enterprises in the case of small scale subsistence agriculture (Mohammed, 2011, Olukosi and Erhabor, 1988).

$G M=G F I-T V C$

Where GM is the Gross Margin, GFI is the Gross Farm Income and TVC is the Total Variable Cost. Gross margin analysis is one method of calculating profitability of small scale cropping enterprises (Olukosiet. al, 2006).

Gross ratio: This is a profitability ratio that measures the overall success of the farm. The lower the ratio, the higher the return per income.

$G R=\frac{T F E}{G I}$

Where GR is the Gross Ratio, TFE is the Total Farm Expenses and GI is the Gross Income.

Operating Ratio: The operating ratio is directly related to the farm variable input usage. The lower the ratio, the higher the profitability of the farm business.

$O R=\frac{T O C}{G I}$

Where OR is the Operating Ratio, TOC is the Total Operating Cost and GI is the Gross Income.

Return on Capital Invested: This is defined as the gross margin divided by total variable cost.

$R I=\frac{G M}{T V C}$

Where RI $=$ Return on Capital Invested, GM $=$ Gross Margin and TVC $=$ Total Variable Cost

Production Function Analysis: Regression model was used to examine the input-output relationship and the implicit form of the model.

$Y=f\left(X_{1}, X_{2}, X_{3}, X_{4}, X_{5}, X_{6} U_{i}\right)$

Where $Y$ is the Output from area crop Production $(\mathrm{Kg}), \mathrm{X}_{1}$ is the farm Size (ha), $\mathrm{X}_{2}$ is the quantity of Seeds $(\mathrm{Kg})$, $\mathrm{X}_{3}$ is the quantity of fertilizer $(\mathrm{Kg}), \mathrm{X}_{4}$ is the labour Input (Man-day), $\mathrm{X}_{5}$ is the Agrochemical (Litres), $\mathrm{X}_{6}$ is the access to Tractor (Dummy Variable were used such as 1 to represent access to Tractor while 0 for otherwise) and $\mathrm{U}_{\mathrm{i}} \mathrm{is}$ for the Error term.

The explicit form of this function takes the following forms:

$Y=a+b_{1} X_{1}+b_{2} X_{2}+b_{3} X_{3}+b_{4} X_{4}+b_{5} X_{5}+b_{6} X_{6}+U_{i}$ (linear)

$Y=a+b_{1} \ln X_{1}+b_{2} \ln X_{2}+b_{3} \ln X_{3}+b_{4} \ln X_{4}+b_{5} \ln X_{5}+b_{6} \ln X_{6}+U_{i}($ semi $\log )$

$\ln Y=a+b_{1} \ln X_{1}+b_{2} \ln X_{2}+b_{3} \ln X_{3}+b_{4} \ln X_{4}+b_{5} \ln X_{5}+b_{6} \ln X_{6}+U_{i}($ doublelog $) \quad 8$

$\ln Y=a+b_{1} X_{1}+b_{2} X_{2}+b_{3} X_{3}+b_{4} X_{4}+b_{5} X_{5}+b_{6} X_{6}+U_{i}(\exp$ onential $)$

Efficiency of Resource-use: This was determined by the ratio of marginal value product of variable (MVP) to marginal factor or product cost (MFC) of inputs based on the estimated regression coefficients (Rahman and Lawal (2003),Iheanachoet al (2003)) efficiency of resource (r).

$r=\frac{M V P}{M F C}$

The rule provides that when $\mathrm{r}=1$, there is efficient use of resource; $\mathrm{r}>1$ and $\mathrm{r}<1$ indicate underutilization and overutilization of a resource respectively. The value of MVP is calculated by using

$M V P=M P P X P_{Y}$

WhileMFC is calculated by using

$M F C=P x_{i}$

Where $\mathrm{P}_{\mathrm{Y}}$ is the Unit Price of output, $\mathrm{Px}_{\mathrm{i}}$ is the Unit Price of input $\mathrm{X}_{\mathrm{i}}$ and $\mathrm{r}$ is the efficiency ratio.

Economies of Scale: This is the measure of farm's success in producing maximum output from a given set of inputs. The elasticity of production (Ep)and return to scale (RTS) were calculated for using

$\sum{ }^{k} E p x_{i}=R T S$ 


\section{RESULTS AND DISCUSSION}

Some socio-economic characteristics of the respondents in the study area were considered. This includes sex, marital status, age, education, household size, years of farming experience and means of land acquisition.

Table1: Socio-economic Characteristics of Sampled Farmers.

\begin{tabular}{lcc}
\hline Variables & Frequency & Percentage (\%) \\
\hline Sex & 95 & 95 \\
Male & 5 & 5 \\
Female & & \\
Marital status & 73 & 73 \\
Married & 18 & 18 \\
single & 6 & 6 \\
divorced & 2 & 2 \\
Widow(er) & & \\
Age & 20 & 20 \\
$21-30 y r s$ & 25 & 25 \\
$31-40 y r s$ & 31 & 31 \\
$41-50 y r s$ & 17 & 17 \\
$51-60 y r s$ & 7 & 7 \\
$>61$ & & \\
Education & 55 & 55 \\
Primary & 30 & 30 \\
Secondary & 13 & 13 \\
Tertiary & 1 & 1 \\
Non-formal & & \\
Household size & 14 & 14 \\
1-5 & 61 & 61 \\
6-10 & 21 & 21 \\
11-15 & 4 & 4 \\
F-20 & & \\
Farming Experience & 16 & 16 \\
6-10yrs & 31 & 31 \\
11-15yrs & 17 & 17 \\
16-20yrs & 17 & 17 \\
Me & 19 & 19 \\
Inherited & & 68 \\
Gift & 68 & 7 \\
purchased & 7 & 25 \\
\hline & 25 &
\end{tabular}

Table1 shows that majority of the respondents were males that is $95 \%$ while only $5 \%$ of respondents were females even though their farming activities were controlled by their husbands or relations as prescribed by religious and traditional beliefs that confined women at home. This is a manifestation of gross inequality in gender distribution and calls for concerted effort in empowering the women in this area. It is also observed that $31 \%$ of the sampled farmers were between the ages of 41 and 50 years(Table 1). Thus, majority of the sampled farmers were middle aged, which could result in a positive effect on production. The educational level of the respondents was also considered; 55\% of the respondents had primary education followed by secondary (30\%) and tertiary (13\%) while that of non-formal education was (1\%). This is not a surprising outcome as the study area falls within educationally disadvantaged part of Kwara State which in turn is affecting the face of agricultural activities in the area. Table 1 also showed that $75 \%$ of the farmers had less than 10 family members while $25 \%$ had 11 to 20 members. Generally, in agrarian settlements, a large family size guarantees free and cheap labour. The table revealed that $16 \%$ of the farmers were within the range of 1-10 years farming experience, while 53\% had 11years and above of farming experience. Table1 also shows that $68 \%$ of the farmers inherited the land in which they are using for farming and $7 \%$ of the farmers got it as a gift or compensation while $25 \%$ purchased the land for farming.

The production function that was used to determine the nature of inputs - output relationship on the effect of mechanisation on arable crops is shown in Table 2 (double-log production function as the lead equation). The value of coefficient of determination $\left(\mathrm{R}^{2}\right)$ indicated that about $43.6 \%$ of variation is explained by 
the inputs included in the regression model, while the remaining $56.4 \%$ is as a result of non-inclusion of some explanatory variables as well as other factors outside the control of the farmer. The regression coefficients of farm size $\left(\mathrm{X}_{1}\right)$, quantity of seed $\left(\mathrm{X}_{2}\right)$, fertilizer $\left(\mathrm{X}_{3}\right)$, labour $\left(\mathrm{X}_{4}\right)$, agrochemical $\left(\mathrm{X}_{5}\right)$, and access to tractor $\left(\mathrm{X}_{6}\right)$ are positive indicating that an increase in each of these variables would lead to an increase in the level of the effect of mechanisationon arable crop production. Conversely, the regression coefficient of labour $\left(\mathrm{X}_{4}\right)$ and agrochemical $\left(\mathrm{X}_{5}\right)$ is negative indicating that a unit increase in this input would lead to a decrease in the level of the effect of mechanisation on arable crops produced. Table 2 also showed that farm size $\left(\mathrm{X}_{1}\right)$, quantity of seed $\left(\mathrm{X}_{2}\right)$, were significant at $1 \%$ levels of probability while access to tractor $\left(\mathrm{X}_{6}\right)$ and agrochemical $\left(\mathrm{X}_{5}\right)$ are significant at $10 \%$ level of probability.

Table2: Estimation double-log Production Function

\begin{tabular}{lcc}
\hline Variables. & Regression coefficient & t-value \\
\hline Constant & 8.124 & $14.053^{* * *}$ \\
Farm size $\left(\mathrm{X}_{1}\right)$ & .273 & $4.092^{* * *}$ \\
Quantity of seed $\left(\mathrm{X}_{2}\right)$ & $1.241 \mathrm{E}-02$ & $.161 \mathrm{NS}$ \\
Quantity of fertilizer $\left(\mathrm{X}_{3}\right)$ & $2.391 \mathrm{E}-03$ & $.022 \mathrm{NS}$ \\
Labour input $\left(\mathrm{X}_{4}\right)$ & $-5.54 \mathrm{E}-02$ & $.800 \mathrm{NS}$ \\
Agrochemical $\left(\mathrm{X}_{5}\right)$ & -.156 & $1.808^{*}$ \\
Access to tractor $\left(\mathrm{X}_{6}\right)$ & .424 & $3.390^{*}$ \\
$\mathrm{R}^{2}$ & .436 & \\
F-RATIO & $11.205^{* * *}$ & \\
\hline
\end{tabular}

***-_Significant at $1 \%$ level of probability

*-- significant at $10 \%$ level of probability.

$N S$-- Not significant

There are several Constraints faced by the farmers but the major ones considered for this study are pests, diseases, pilfering, inadequate rainfall and inadequate credit facilities. Table 3 below shows the frequency distribution constraints faced by the farmers within the two local government areas under consideration.

Table 3: Frequency distribution of constraints.

\begin{tabular}{cccc}
\hline Constraints & Variables & Frequency & Percentage (\%) \\
\hline Pest & Affected & 53 & 53.0 \\
& Not Affected & 47 & 47.0 \\
Disease & Affected & 79 & 71.0 \\
& Not Affected & 21.0 & 21.0 \\
Pilfering (theft) & Affected & 25 & 25.0 \\
& Not Affected & 75 & 75.0 \\
Inadequate rainfall & Affected & 63 & 63.0 \\
& Not Affected & 37 & 37.0 \\
Inadequate credit facility & Affected & 21 & 21.0 \\
& Not Affected & 79 & 79.0 \\
\hline
\end{tabular}

It can be observed from Table 3 above that the farmers affected by pest are 53\%, those affected by disease are $21 \%$, pilfering (theft) of farm products is $25 \%, 63 \%$ of the farmers complain of inadequate rainfall to accommodate their farming activitieswhile those that benefited from loan either from the Federal, State, Local Governments and International Organisations were only $21 \%$ in the study area.

Table 4: Output on tractor use.

\begin{tabular}{lcccc}
\hline Variable & t-value & p-value & Level of sig. & decision \\
\hline Output with tractor & -5.166 & 0.000 & $\mathrm{P} \leq 0.001$ & significant \\
use & & & & \\
Vs & & & & \\
Outputwithout & & & \\
tractor use & & & \\
\hline
\end{tabular}

It can be observed from Table 4 that there is significance in the output of those that use tractor over those that do not use tractor.

Agricultural development is of paramount importance in almost every country of the world, there is need to feed additional millions of people being added to the world population each year, and to also improve the present insufficient 
food provision per person. This will require faster agricultural mechanisation development, particularly in a developing economy of the third world country like Nigeria.

\section{CONCLUSION}

From the result of the analysis and interpretation of data carried out on the effect of mechanization on arable crop in both Edu and Patigi local government areas of Kwara state, where most of the farmers are small farm holders with most of their land fragmented, and individual farm size not more than, 5 hectares and most of their labour coming from manual source.With the introduction of mechanisation, there is a positive impact on farm productivity and income, where farmers accept the use of tractor in their farming activities. The capital of the farmer should be improved, in order to acquire or to hire tractors, so as to satisfy the demand of production, through loan etc. There is need for the government and other organizations to provide a forum for education for the rural farmers on how to adopt and accept the modern technology in agriculture.Application of modern agricultural technology enables the cultivation of more lands and ensures timeliness in operation and better tillage. Modern technology in agriculture in the study area has high potentials in increasing farm productivity. In general, mechanisation has an effect on the roles and task patterns of men and women on the farm. Gender issues therefore have to be taken into account when discussing mechanization and formulating policies.

\section{RECOMMENDATION}

1. Government should educate the farmers more on the benefit mechanization.

2. Government should provide financial assistance to the farmers without much difficulty so as to acquire tractors and other farm machineries through loan etc, if the benefit of mechanization is to be fully reaped.

3. Government should try and look into the Gender issues in the study area.

[1] CTA. (1992): Tools for Agriculture Intermediate Technology Publication. Southampton Row, London WCIB 4HH UK: $103-105$

[2] Dauda S.M., Agidi G. and Shotunde M.A. (2010): Agricultural Tractor Ownership and Off-Season Utilization in Ogun State South Western Nigeria, African Journal of Agricultural, 6 (3): 95-103.

[3] Iheanacho, A.C., Olukosi, J.O. and Ogungbile A.O. (2003): Economic efficiency of resource-use in millet based cropping systems in Borno State of Nigeria, Nigerian Journal of Tropical Agriculture. 2: 33 - 42.

[4] Kaumbutho, P. G. (1996): 'Chairperson's Welcome Address', in P. G. Kaumbutho et al. (eds) Meeting the Challenges of Draught Animal Technologies in Kenya. Proceedings of workshop held on 27-31 March 1995, KENDAT, University of Nairobi.

[5] Manuwa S.I (1996): Management of Agricultural Tractors and implements in tropical setting in Nigeria.Paper presented at the $17^{\text {th }}$ annual conference of N.S.A.E. Federal University of Technology Akure, Nigeria.

[6] Mohammed S. (2011): Economics of rainfed and irrigated rice production under upper Benue River basin development authority scheme, Dadinkowa, Gombe state, Nigeria.Continental J. Agricultural Economics 5 (1): 14 22.

[7] Olukosi, J.O Isitor, S.U. and Ode, M.O. (2006): Introduction to agricultural marketing and prices: principle and application. Living Book Series, GU publications Abuja, 115p

[8] Olukosi, J. O. and Erhabor, P. O. (1988): Introduction to Farm Management Economics: Principles and Application, Agitab publishers Limited, Zaria, 109p

[9] Oni K.C. (1996): Effective Management and Maintenance of Agricultural Tractor in Nigeria. Paper presented at the annual conference of NSAE, O.A.U, Ile-Ife, Nigeria.

[10] Oudman, L. (1993): The Animal Draught Power Development Project in the Department of Agricultural Engineering, in C. L. Kanali et al. (eds) Improving Draught Animal Technology. Proceedings of the first conference of the KENDAT,University of Nairobi: 106-116.

[11] Owombo P.T., Akinola A.A., Ayodele O.O. and Koledoye G.F. (2012): Economic Impact of Agricultural Mechanization Adoption: Evidence from Maize Farmers in Ondo State, Nigeria. Journal of Agriculture and Biodiversity Research, 1(2): 25-32.

[12] Rahman, S. A. and Lawal, A. B. (2003): Economic analysis of maize-based croppingsystems in Giwa Local Government Area of Kaduna State, Nigeria, An InternationalJournal of Agricultural Sciences, Science, Environment and Technology. 3:139-148.

[13] Rahman, A and Mijinyawa, Y. (2001): Assessment of Tractor Hiring Service in Lagos State Proceeding of the international conference of the Nigeria Institution of Agricultural Engineers, 23: 71-74

[14] Usman, A.M. and Umar, B. (2003): Farm tractor Maintenance: Types, Procedures and Related Problem in Nigeria. Proceedings of the 4th international conference of Nigeria institution of Agricultural Engineers, 25: 78-84. 